\title{
NOTA DO EDITOR
}

O presente exemplar chega aos estudiosos e pesquisadores em momento de renovação do Departamento de Música da ECA-USP. No dia 25 de agosto último, passamos a ocupar o novo prédio construído especialmente para a Música, obedecendo a critérios arquitetônicos precisos. Salas de aulas especiais; pequenas salas de estudo individualizadas; salas de professores; seção administrativa; auditório com 105 poltronas, mas quepodereceber 150 ouvintes; laboratório eletroacústico a ele acoplado, destinado, entre outros desideratos, a gravar eventos específicos sob o aspecto repertorial; e mais - doravante fundamental à pesquisa musicológica na Universidade - o espaço destinado ao Centro de Difusão e Estudos da Música Brasileira (CDEMB) constituem as dependências do novo prédio do Departamento de Música. Este situase geográfica e harmoniosamente próximo aos outros prédiosigualmente destinados às Artes: Departamento de Teatro, Escola de Arte Dramática e, a médio prazo, Departamento de Artes Plásticas, todos inseridos no já denominado Conjunto Arquitetônico das Artes.

Quanto ao CDEMB, haverá uma intrínseca ligação com a Revista Música. Às 1.200 partituras, inéditas ou não, somam-se as recentes e preciosas doações do acervo do compositor Henrique Oswald (18521931), da coleção da família, e mais o conjunto de manuscritos autógrafos do contemporâneo Gilberto Mendes (1922) cedido pelo compositor. A exegese que se fará mister de todo o acervo permitirá, a nível de Pesquisa, Pós-Graduação e Pós-Doutorado, gerar estudos e ensaios para a Revista, assim como, paulatinamente, a edição crítica a partir de equipes especializadas. Esperamos, no tempo necessário ao desvelar seguro, divulgar a listagem de todo o patrimônio documental, a fim de que pesquisadores extramuros encontrem, no CDEMB, caminhos que propiciem respostas às perenes indagações quanto aos processos envolvendo a criação da música brasileira.

- A Revista Música manterá, como princípio básico, o desvio da endogenia - que pode revelar um acomodamento do pensar - através da 
inserção de ensaiose estudos de pesquisadoresinternacionais renomados, que servem à comparatividade e ao conhecimento de metodologias outras. A manutenção do visual da Revista apenas sofreu alteração na imagem de fundo da capa. À reprodução de uma página de manuscrito mineiro do século XVIII preferenciou-se doravante, igualmente como fundo, a visão da fachada do novo prédio do Departamento de Música da ECA-USP.

A Universidade de São Paulo dá um passo decisivo em direção à modernidade, pois as nomenclaturas tradicionais utilizadas para os Departamentos de Artes nas principais Universidades, abaixo ou acima do Equador, são a evidência da importância da Arte no longo caminho em direção ao desvelar. É possível captar-se, apesar de inúmeras dificuldades a vencer, a vibratilidade hoje existente no novo espaço à música destinado eque, acreditamos, teráa continuação através de todos os envolvidos com a causa artístico-musical. 